\title{
Influence of the regional climate variations on lake changes of Zabuye, Dangqiong Co and Bankog Co salt lakes in Tibet
}

\author{
WANG Yunsheng ${ }^{1,2},{ }^{*}$ ZHENG Mianping ${ }^{1,2}$, YAN Lijuan ${ }^{3}$, BU Lingzhong ${ }^{1,2}$, \\ QI Wen ${ }^{1,2}$ \\ 1. MLR Key Laboratory of Saline Lake Resources and Environments, Institute of Mineral Resources, Chinese \\ Academy of Geological Sciences, Beijing 100037, China \\ 2. R\&D Center for Saline Lakes and Epithermal Deposits, Chinese Academy of Geological Sciences, Beijing \\ 100037, China \\ 3. Chinese Academy of Geological Sciences, Beijing 100037, China
}

\begin{abstract}
The lake hydrological and meteorological data of the Tibetan Plateau are not rich. This research reports the observed climatic data and measured water levels of saline lakes from the local meteorological stations in the Zabuye salt lake, the Dangqiong Co salt lake and the Bankog Co salt lake in recent two decades. Combining with satellite remote sensing maps, we have analyzed the changes of the water level of these three lakes in recent years and discussed the origins of the changes induced by the meteorological factors. The results show that the annual mean temperature and the water level reflect a general ascending trend in these three lakes during the observation period. The rising rates of the annual mean temperature were $0.08^{\circ} \mathrm{C} / \mathrm{yr}$ during $1991-2014$ and $0.07^{\circ} \mathrm{C} / \mathrm{yr}$ during 2004-2014, and of the water level, were $0.032 \mathrm{~m} / \mathrm{yr}$ and $0.24 \mathrm{~m} / \mathrm{yr}$, respectively. Analysis of changes of the meteorological factors shows the main cause for the increase of lake water quantity are the reduced lake evaporation and the increased precipitation in the lake basins by the rise of average temperature. Seasonal variation of lake water level is powered largely by the supply of lake water types and the seasonal change of regional climate.
\end{abstract}

Keywords: Tibetan Plateau; saline lake; climate variation; lake change

\section{Introduction}

With the development of the global warming, the research of environmental changes taking place in the Tibetan Plateau has become the focus of global concern. As a special body of

Received: 2018-10-19 Accepted: 2019-03-15

Foundation: The Key Scientific Research Project of National Science and Technology Commission, No.K89-01-32; National Natural Science Foundation of China, No.4907010123; Special Scientific Research Projects in Public Welfare Profession of Ministry of Land and Resources of the People's Republic of China, No.201011001; Basic Research Fund, No.K1418

Author: Wang Yunsheng, Associate Professor, specialized in saline lake environment and comprehensive utilization of brine resources. E-mail: wys0907@aliyun.com

"Corresponding author: Zheng Mianping, Professor, E-mail: zhengmp2010@126.com 
water, the salt lake is closely related to the factors of atmosphere, soil and biology, and has obviously sensitive responses to the change of climate and environment system (Zheng et al., 2000, 2004; Liu et al., 2009; Kang et al., 2010; Song et al., 2014a). The alpine lakes which are in the natural state are less affected by human activities and can reflect the climate condition realistically. The Tibetan Plateau is a multi-lake distribution area in China. As the highest plateau and with the most abundant resources on earth, there are many saline lakes and salt water lake groups (Chang, 1987; Zheng, 2014). The research on plateau lakes is helpful to reveal the environmental evolution characteristics of the Tibetan Plateau and even the whole country.

Recent studies show that the water level of most of the lakes in Tibet region has risen (Qi and Zheng, 2006a; Bianduo et al., 2009; Lei et al., 2013; Yan and Zheng, 2015a; Ma et al., 2016). The main reasons for this are the increase of annual precipitation, the amount of glacier melting and the melting of the frozen soil due to the increase of the annual mean temperature (Yao et al., 2007; Ye et al., 2008; Zhu et al., 2010; Wang et al., 2013; Ma et al., 2016). However, direct meteorological or hydrological observation data in the target saline lake are extremely scarce. The above research results are based on the interpretation of remote sensing images and the data from the weather station of administrative region where saline lake is located (Jiang et al., 2017; Song et al., 2014b; Zhu et al., 2010). In fact, the northern Tibetan Plateau is vast in territory and complicated in topography. The impact of seasonal variation of climate in the saline lake area is also very significant. In order to get a thorough knowledge about the climate environment of the lake basin and the reasons for the change of the lake area, the climate change characteristics and the response of the water level and the lake area to meteorological factors in the central-south of the Qiangtang (Changtang) Plateau are analyzed in this paper. And datasets for the study on regional response of global change are provided.

\section{Study area and data}

\subsection{Study area}

The study area is located in central and western lake basin of northern Tibetan Plateau, including Zabuye, Dangqiong Co and Bankog Co (Figure 1). Zabuye salt lake $\left(31^{\circ} 14^{\prime}-\right.$ $\left.31^{\circ} 33^{\prime} \mathrm{N}, 83^{\circ} 52^{\prime}-84^{\circ} 23^{\prime} \mathrm{E}\right)$ and Dangqiong Co $\left(31^{\circ} 30^{\prime}-31^{\circ} 40^{\prime} \mathrm{N}, 86^{\circ} 38^{\prime}-86^{\circ} 49^{\prime} \mathrm{E}\right)$ lie on the western Tibetan Plateau, which belong to semi-arid climate zone of the Qiangtang Plateau. In the region, the climate shows strong radiation, low temperature, less precipitation and large evaporation. And the supply of the lake mainly depends on the precipitation and snow melt water. Zabuye Basin is a typical inland basin, and salt lake is the lowest point of confluence. It is divided into two lakes, north lake and south lake. The water area is $235 \mathrm{~km}^{2}$. The Lunggar glacier sits close to the west of Zabuye. Water system in Zabuye area developed well, such as Luobujuqu, Jiaobuqu, Langmengaqu and Quanshui River and so on. The Luobujuqu is a perennial river, and the others are the stream rivers in rainy seasons and subsurface-flow in dry seasons. In addition, there is a lot of spring water around the lake. Zabuye Spring and Qiukuang Spring are two of them which have the maximum water inflow. The flow rate was not influenced by the season, having no direct relation with the rainy season precipitations. The area of Dangqiong Co is $56 \mathrm{~km}^{2}$, its basin is high in southeast and 
low in northwest. The southern mountains are covered with snow all the year round. Geqianqiong, Qurebaima and Miangkangluoma are perennial rivers in Dangqiong Co basin. Bankog Co $\left(31^{\circ} 42^{\prime}-31^{\circ} 45^{\prime} \mathrm{N}, 89^{\circ} 29^{\prime}-89^{\circ} 5^{\prime} \mathrm{E}\right)$ lies on the central Tibetan Plateau, and the supply mainly depends on surface rainfall and surface runoff. Bankog Co, Zabuye and Dangqiong Co are all carbonate type saline lakes. The latter two are rich in $\mathrm{Li}, \mathrm{K}, \mathrm{B}, \mathrm{Rb}$ and Cs (Zheng et al., 2000, 2004; Zheng, 2014). They serve as important liquid mineral resources with great values of exploitation.

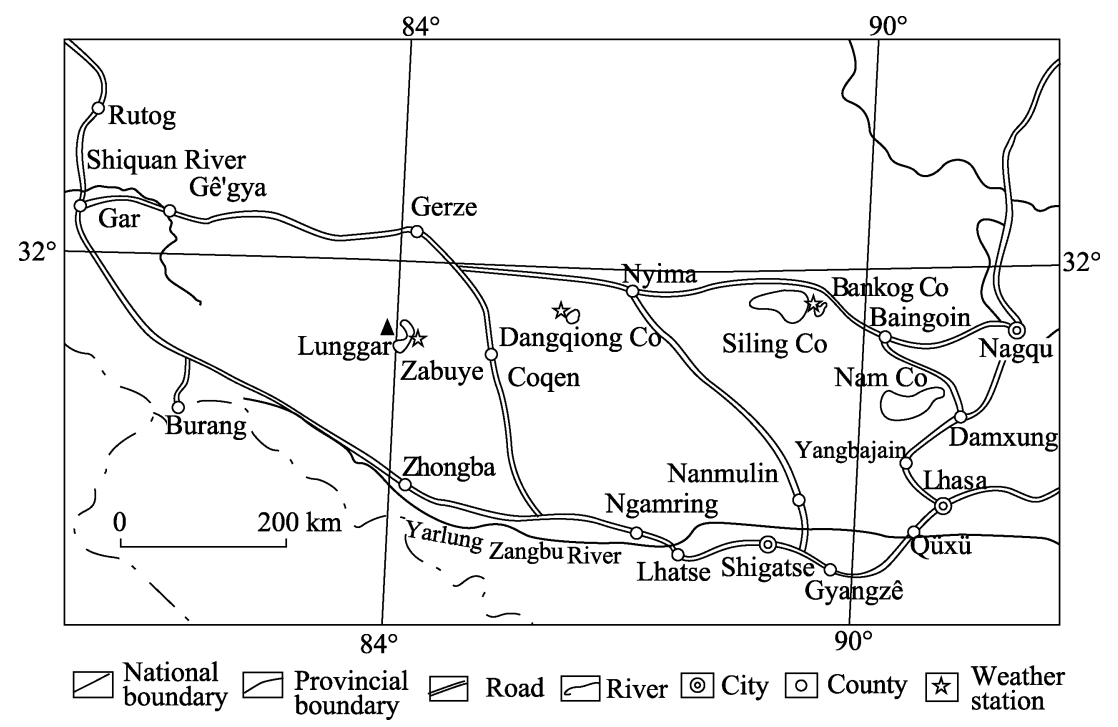

Figure 1 Geographic sketch map of Zabuye, Dangqiong Co and Bankog Co salt lakes

\subsection{Data acquisition and preprocessing}

Chinese Academy of Geological Sciences established three long-term saline lake meteorological observation stations in the above three saline lake districts in 1990, 2001 and 2004 respectively(Qi et al., 2006a). During the observation period, TRM-ZS2 high precision automatic meteorological station and LS206B propeller-type velocity meter were used. A large number of meteorological, hydrological and hydrochemical data were obtained for the first time in these districts. Although the running times of the three stations were different, the available measured data can reflect the change of lake area since the 1990s in general. It has scientific and practical significance for the study on dynamic change of lakes in the hinterland of the Tibetan Plateau and comprehensive utilization of lithium and potassium resources.

Water level observation points were located at the north and south sides of the three lakes. In general, water level was recorded once a week before 1998 and twice a month after 1998. In this paper we use the average monthly value to indicate water level. From January 1991 to December 2013, the number of missing data in the Zabuye salt lake was 33 and accounted for 14.1\% of all data. From May 2004 to December 2013, the number for Dangqiong Co salt lake was 4 months and accounted for $5.6 \%$ of all data. And the data in Bankog Co salt lake was complete from May 2001 to October 2003. The velocities of rivers and springs around the salt lake were determined by velocity meter at fixed point. The flow rate was approxi- 
mately equal to velocity multiplied by sectional area of riverbed. According to incomplete survey, the average annual runoff in Zabuye basin was $6.672 \times 10^{7} \mathrm{~m}^{3} / \mathrm{yr}$ during the period from 2001-2010. In Dangqiong Co basin, the average annual runoff was $3.6 \times 10^{6} \mathrm{~m}^{3} / \mathrm{yr}$ during the period 2004-2010. The main recharge source of Bankog Co is Kawazangbu River, and the supply failed to be counted because Bankog Co connects its adjacent mother lake.

In this paper, we used 120 Landsat MSS/TM/ETM images covering the study area to retrieve data on the saline lake surface extent for 1990-2013. The spatial resolution of images is $30 \mathrm{~m}$. All of the images selected are cloud free or have only slight cloud cover (less than $5 \%)$.

\section{Results}

\subsection{Annual mean temperature variation}

The study shows that the change of annual mean air temperature is helpful to understand the characteristics of climate change and predict climate disasters, which has great significance to disaster prevention and reduction. The average value is used to analyze and discuss the meteorological elements in this section because it can better reflect the change of climate characteristics.

Several researchers argue that the general characteristics of climate change in the Tibetan Plateau are temperature rise, precipitation increase, potential evapotranspiration decrease and the trend from dry to humid status in most areas (Wu et al., 2005; Du, 2001; You et al., 2010). According to statistics, the annual mean temperature of the Zabuye salt lake began to rise gradually from 1991 and reached a high value in 1998, although there was a significant drop in 1997 (Figure 2). The mean temperature change was smaller from 1998 to 2008, but it had a significant increase during the period 2009-2013. In the above three periods, the mean temperature of the Zabuye salt lake was $2.23,2.71$ and $3.67^{\circ} \mathrm{Crespectively.} \mathrm{The} \mathrm{rise}$ rate of annual mean temperature was $0.08^{\circ} \mathrm{C} / \mathrm{yr}$ from 1991 to 2013 . Similar changes have taken place in the Dangqiong Co salt lake. The mean temperature raised from $3.2^{\circ} \mathrm{C}$ in 2004 to $4.6^{\circ} \mathrm{C}$ in 2014 . The rise rate of annual mean temperature in the lake was $0.07^{\circ} \mathrm{C} / \mathrm{yr}$. Based on the meteorological data of Bankog Co from June 2001 to October 2002, the mean temperature was $0.1^{\circ} \mathrm{C}$ and higher than the value provided by predecessors. The latter was -1 to

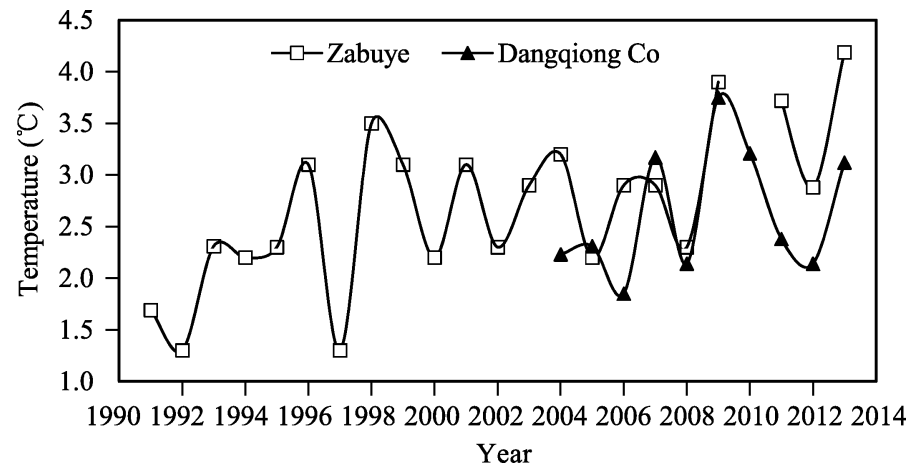

Figure 2 The mean temperature of Zabuye and Dangqiong Co salt lakes 
$-2^{\circ} \mathrm{C}$. Meanwhile, the upward trend from 2000 to 2011 was more obvious (Zhao et al., 2004; Du et al., 2014). Generally, the highest temperature was usually observed in June and July, the lowest in December and January of the following year.

Previous studies (Niu et al., 2004; Lu et al., 2005; Yao et al., 2006; Zheng et al., 2002) also showed that the 1960s was a relatively low temperature period in the Tibetan Plateau; the temperature began to rise in the 1970 s, then came another relatively high temperature period in the mid-1980s, and the heating up was more obvious in the 1990s. In recent 50 years, the temperature has been increasing in fluctuation in the Tibetan Plateau, and the annual mean temperature in most areas rose and peaked in 1998 (Ma et al., 2003).

\subsection{Annual evaporation, precipitation, and sunshine hours}

\subsubsection{Annual evaporation, precipitation}

Lake evaporation is one of the main factors affecting the water level of saline lakes. According to statistics, the average annual evaporation of Zabuye salt lake was $2491.54 \mathrm{~mm}$ from 1991 to 2013. Dangqiong Co salt lake was $2361.19 \mathrm{~mm}$ from 2004 to 2013 (Figure 3). And Bankog Co was $1978.1 \mathrm{~mm}$ from 2001 to 2002 (Zhao et al., 2004).

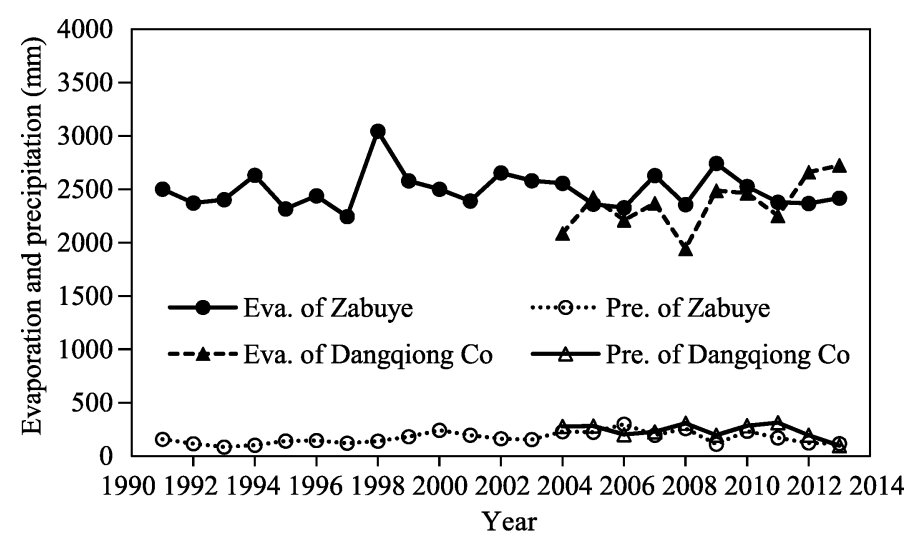

Figure 3 Annual evaporation and precipitation of Zabuye and Dangqiong Co salt lakes

From April to September, evaporation kept a high value and relatively low in the whole ice-free period. Similar to temperature, the maximum evaporation emerged in June and July, the minimum emerged in December and January of the following year. The difference between the maximum and minimum evaporation of the two lakes varied from 300.6 to 420.7 $\mathrm{mm}$ and 187.6 to $486.4 \mathrm{~mm}$ respectively. The value of other months gradually changed from low to high or high to low. During the rainy season, evaporation was reduced because the air humidity was high. In addition, there was a certain relationship between evaporation and wind strength. In general, the evaporation can be increased with the wind getting strong.

According to the observation data in the last 19 years, the precipitation of Zabuye salt lake was more concentrated from the beginning of late July to the end of September. Rainfall predominated in the rainy season was more than $90 \%$ of the total annual rainfall. The annual mean precipitation was $170.2 \mathrm{~mm}$, in which the rainfall was dominant and the amount of snow (hail) was relatively small. Similarly, the rainfall of Dangqiong Co salt lake was more concentrated in the third quarter, accounting for more than $80 \%$ of the total annual rainfall. 
The mean annual precipitation was $238.38 \mathrm{~mm}$ between 2004 and 2013 (Figure 3). The rainfall of Bankog Co was $263.9 \mathrm{~mm}$ between 2002 and 2002. Overall, there was little precipitation in winter in the three lakes.

\subsubsection{Annual sunshine hours}

Those three salt lakes are very rich in solar energy, with the weather being mainly sunny or cloudy, rarely overcast and of thunderstorm. The results showed there was a significant decline before 2008 and then increased again in Zabuye salt lake area. The annual mean sunshine duration was 2883.0 hours (Figure 4). There were 280 days of more than 7.2 hours sunshine duration, making up $76.7 \%$ of the annual sunshine amount. The mean annual sunshine hours of Bankog Co and Dangqiong Co were 2447.6 and 2158.2 hours (Figure 4), and there were fewer days with more than 7.2 hours sunshine duration than in Zabuye salt lake. The distinction in sunshine duration between Zabuye and Dangqiong Co reflected in their salinity. Brine salinity of Zabuye salt lake was 30\% and far more than Dangqiong Co. This illustrated that more sunshine was conducive to the enrichment of saline lake brine.

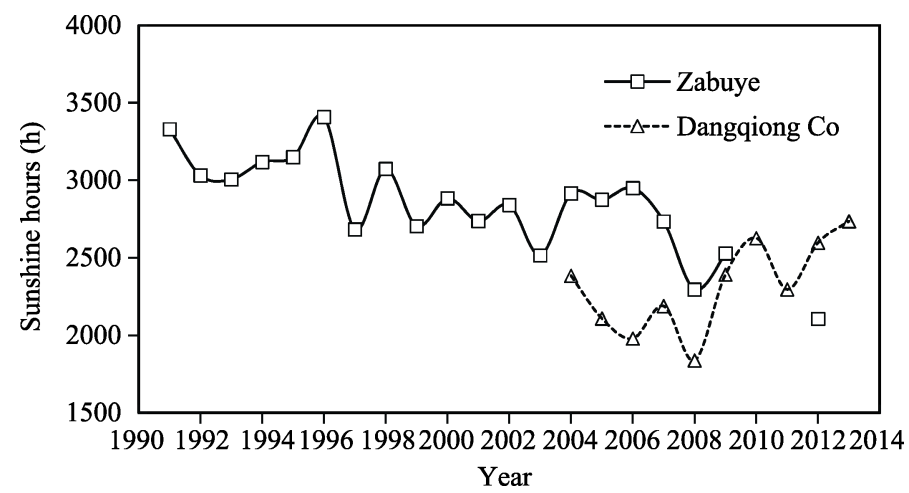

Figure 4 The sunshine duration of Zabuye and Dangqiong Co salt lakes

\section{Discussion}

\subsection{Response of saline lake changes to climate fluctuation}

As typical lake with glacial supplies in the central hinterland of the Tibetan Plateau, it is very important to study the law between the fluctuation of water level and climate change in Zabuye and Dangqiong Co.

The change of water level and its composition are highly sensitive and dependent on natural factors, and researchers can estimate the changes of climate according to the changes of the lake environment. For example, the water level in Qinghai Lake in recent years has dropped due to long-term climate changes and short-term fluctuations (Zhou et al., 1992; Shi et al., 2005), and the lake level of Ebinur (Aibi) and Aydingkol (Aiding) lakes in Xinjiang has been raised because of the increase of glacier melting and precipitation in the lake districts (Shi et al., 2007).

\subsubsection{Dangqiong Co salt lake}

Based on historical data of the Dangqiong Co over years, the change of water level was obviously influenced by temperature and precipitation. Because there was little precipitation in 
winter, water level dropped to the lowest point in January and February. As the day warmed up, the secondary peak was shown with the glaciers melted. After the maximum precipitation in June and July, the water level emerged the highest point in August and September. During the period from 2004 to 2014, the water level ascended to $2.2 \mathrm{~m}$ and the increase rate was $0.24 \mathrm{~m} / \mathrm{yr}$ (Figure 5). The water level increased in two periods, 2004-2007 and 2010-2012. The increase rates were $0.144 \mathrm{~m} / \mathrm{yr}$ and $0.247 \mathrm{~m} / \mathrm{yr}$ respectively. It is worth noting that the mean temperature value of 2008 was the lowest during the period, and the water level reached the highest value in the rainy season with the highest-ever precipitation. Again the similar case occurred in 2010 and 2012.

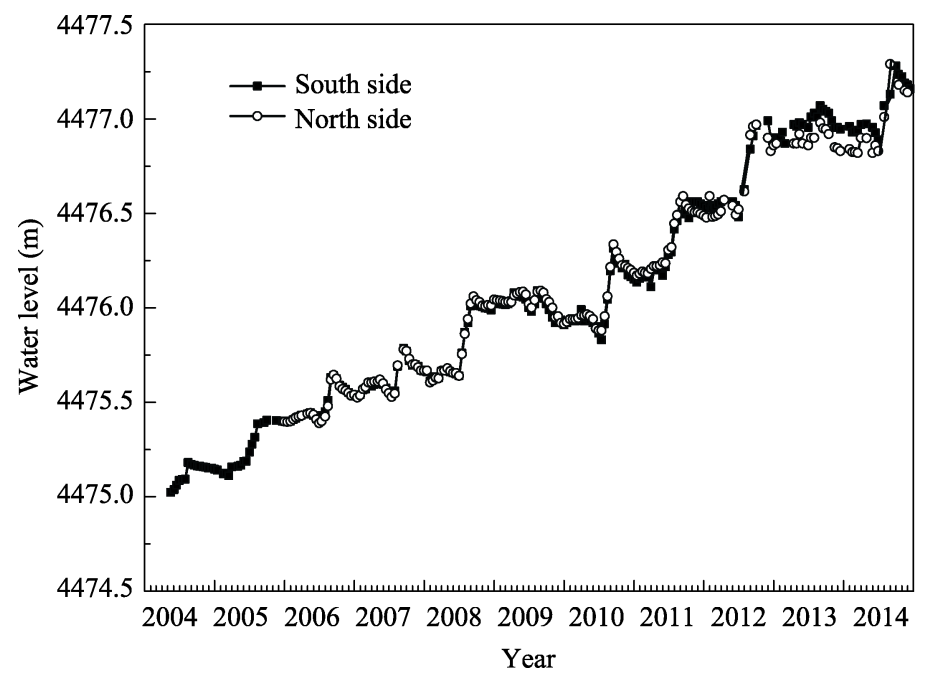

Figure 5 Water level fluctuating recorded in Dangqiong Co salt lake during 2004-2014
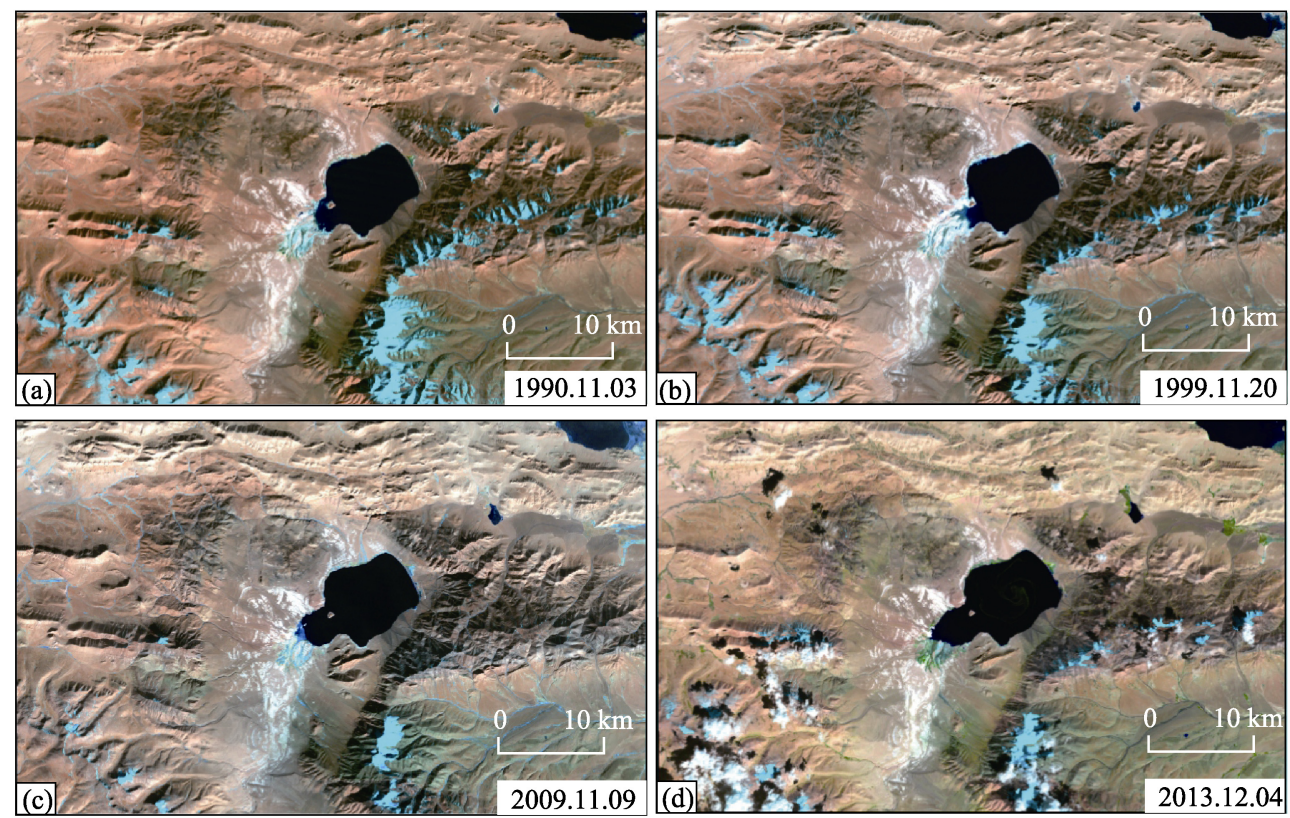

Figure 6 Remote sensing images of Dangqiong Co salt lake 
According to the result of remote sensing image interpretation, Dangqiong Co salt lake has a trend for expanding in both depth and extent from 2004 to 2014 (Figure 6). Based on the meteorological data of Shenzha county, the nearest county to Dangqiong Co salt lake, the mean temperature in the period from 2001 to 2010 rose by $1.38^{\circ} \mathrm{C}$ compared with the period from 1961 to 1970 . The average growth rates of temperature and precipitation were $0.314^{\circ} \mathrm{C} / 10 \mathrm{yr}$ and $19.13 \mathrm{~mm} / 10 \mathrm{yr}$ respectively, while the evaporation decreased based on the results of previous studies (Yan and Zheng, 2015a, 2015b; Ma et al., 2016). The temperature rise made the ice on the mountains of the south area melt, increasing the amount of water in rivers that drain into the lake. According to statistics, the area of glaciers has been reduced by about $24.35 \mathrm{~km}^{2}$ from November 1990 to November 1999 . The descending value was increased to $77.90 \mathrm{~km}^{2}$ from November 1999 to November 2009 and the area of the lake increased by $12.55 \mathrm{~km}^{2}$.

The enlargement in snow melt and rainfall has increased the supply of lake water. With the decrease of evaporation, lake area was larger. Dangqiong Co increased from $56.49 \mathrm{~km}^{2}$ to $64.61 \mathrm{~km}^{2}$ during the observation period from November 2001 to November 2013 (Figure $6)$. It rose by $14.37 \%$ in the 12 years. This was consistent with the trend of global warming and gradual decrease of glaciers. Meanwhile, the evaporation on the surface of lakes was aggravated. The main reason for the large reduction in glacier area in 2009 was: the winter temperature has been second high in the Tibet region since 1971, leading to a large reduction in glaciers.

\subsubsection{Zabuye salt lake}

Based on historical data of the Zabuye salt lake over years, the lowest point of water level in south lake appeared in July and August, and the highest point, in December or January of next year. The water level change of north lake is different from that of south lake. Before 1996, the lowest point of water level appeared in November and December, and the highest point in April. While after 1998, the lowest point of water level appeared in June and July, and the highest point in August and September (Qi et al., 2006a, 2006b), rising in a fluctuating way within this period. And the second peaks appeared in May and June.

The change characteristics in south and north lakes of Zabuye were different due to the supply types. The underground springs were the main supply of water in south lake and the precipitation in the catchment basin was the less prominent part. The main factors that determine the water level of saline lakes were air temperature and evaporation because the groundwater flow was relatively stable. It can be concluded from water level change curve that there was negative correlation between the water level of the south lake and the air temperature, and evaporation. Both the air temperature rising and the evaporation increasing caused a drop in the water level and vice versa.

Compared with south lake, there is positive correlation between water level of the north lake and the air temperature. Both the air temperature rising and the evaporation increasing caused a rise in the water level and vice versa. Geographically, the Lunggar glacier sits close to the west of Zabuye and its meltwater flows into the north lake. Based on the field observation results and previous studies (Yao et al., 2007; Ye et al., 2008), we believe glaciers meltwater was the main contribution factor besides atmospheric precipitation.

The average water level of the south lake dropped by $11 \mathrm{~cm}$ from 1991 to 2001, and for 
the north lake, by $9.7 \mathrm{~cm}$ from 1991 to 1996 . The water level of the south and north lakes decreased because the mean temperature and evaporation of the saline lake basin increased continuously and rainfall decreased. It is a sign of regional arid climate in Zabuye saline lake basin. Before 1998, the water level of the south lake was higher than that of the north lake. The water level of the north lake jumped and exceeded that of the south lake in 1999. From 2002 to 2009, the water level of the south lake ascended by $48.5 \mathrm{~cm}$, and for the north lake, by $69.8 \mathrm{~cm}$ from 1997 to 2009 (Figure 7). Particularly, since 2009 the north lake has double peak which usually occurs in April and August. By comparison, the peak value of August is higher than that of April. The results also show that the precipitation in the rainy season has a faster and more obvious effect on supplying lake water, but only has a marginal effect on the general trend of Zabuye salt lake. After 2010, the water level of the north lake was higher than that of the south lake and both have a little change with seasons.

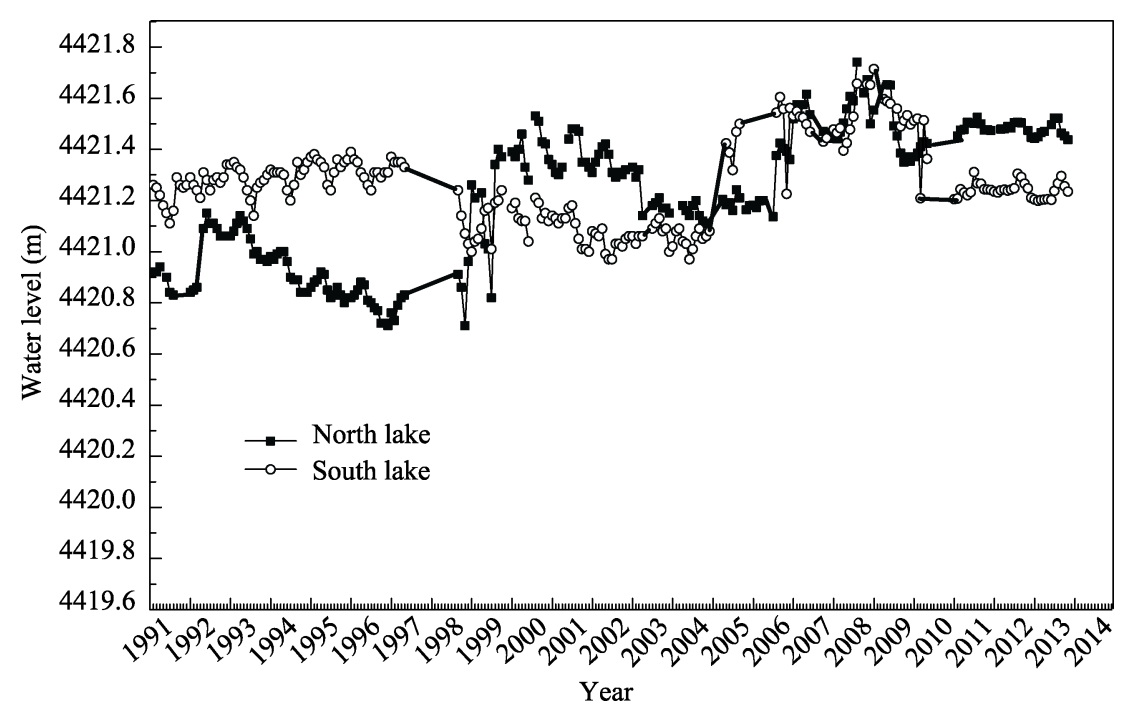

Figure 7 Water level fluctuating recorded in Zabuye salt lake during 1991-2014

Based on the result of remote sensing image interpretation, the area of Lunggar snow mountains which lie on the northwest side of Zabuye salt lake decreased by nearly $30 \mathrm{~km}^{2}$ from 1976 to 2014, and the area of Zabuye salt lake in the same period increased from 137 $\mathrm{km}^{2}$ to $235.97 \mathrm{~km}^{2}$ (Figure 8). The increasing extents of the south lake and the north lake were different because of the difference in the lake basin depth. The area of the north lake increased by $17.24 \mathrm{~km}^{2}$, and for the south lake, by $81.74 \mathrm{~km}^{2}$. The area of Zabuye salt lake increased by $72.25 \%$ over the past 23 years.

\subsubsection{Bankog Co salt lake}

Because of the periodic decline of the Siling Co surface, sand spits extended to the lake from both sides of the north and south connected at the final phase of the late Pleistocene. Bankog Co has been isolated and located in the east of the Siling Co. According to research, from 1959 to 2003, the lake surface of the Bankog Co was overall rising, reaching up to $1.75 \mathrm{~m}$, although from 1959 to 1973 or a little later, there occurred a process of first falling, then rising and again slight falling, with a fall of $0.25 \mathrm{~m}$, and an accompanied contraction of the 
lake area (Zhao et al., 2011). During the observation period from 2001 to 2003, annual variations of water level were $0.2 \mathrm{~m}$ to $0.47 \mathrm{~m}$ (Figure 9). In August 2001, it reached the maximum value, $4522.11 \mathrm{~m}$. During this period, the decline of water level in rainy season and dry season was 0.1 and $0.38 \mathrm{~cm}$ respectively (Zhao et al., 2006).

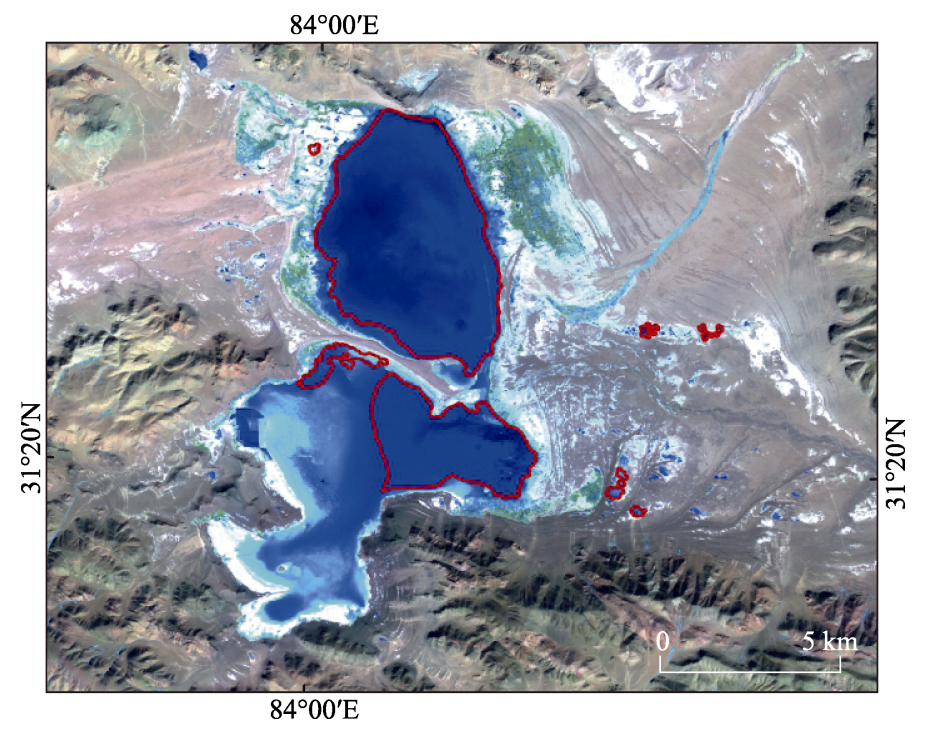

Figure 8 Remote sensing images of Zabuye salt lake

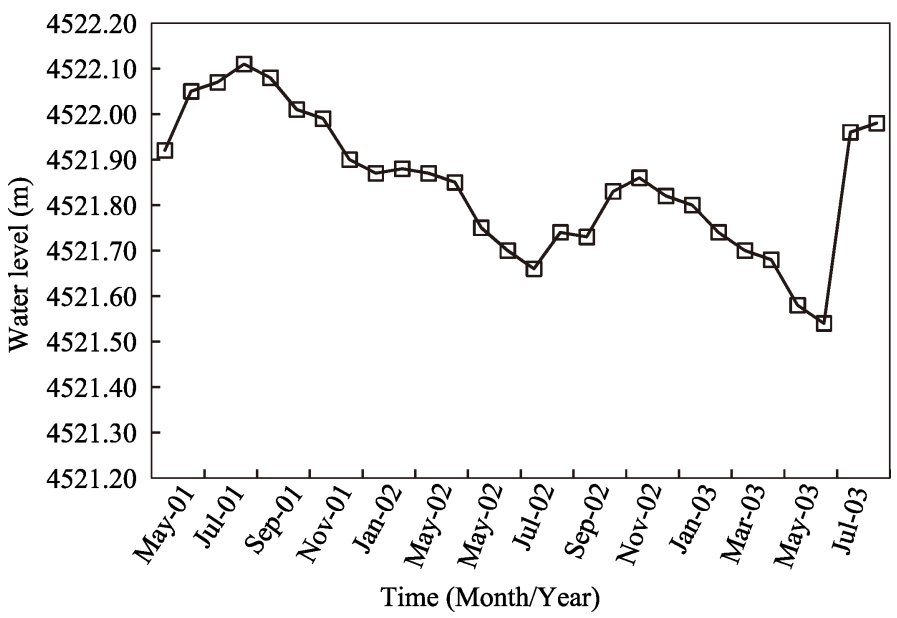

Figure 9 Water level fluctuating recorded in Bankog Co salt lake during 2001-2003

Based on previous studies and the result of remote sensing image interpretation, the area of Bankog Co has a trend of expansion from 1977 to 2010. The overall trend of mean temperature was increasing in Baingoin county after 1973. Mean temperature between 2001 and 2010 was $2.18^{\circ} \mathrm{C}$ higher than the value between 1961 and 1970, and average speed of growth was $0.545^{\circ} \mathrm{C} / 10 \mathrm{yr}$. Meanwhile, evaporation tended to decrease (Yan and Zheng, 2015a, 2015b; Ma et al., 2016). The enlargement in snow melt and rainfall has increased the supply of the basin. With the decrease of evaporation, lake area was bigger. The lake area 
increased from $41.4 \mathrm{~km}^{2}$ in February 1977 to $131.82 \mathrm{~km}^{2}$ in August 2010 (Figure 10). The increased water volume in saline lake has led to lower salinity and ion concentration of lake water. The salinity of Bankog III dropped from $221.90 \mathrm{~g} / \mathrm{L}$ in 1976 to $46.72 \mathrm{~g} / \mathrm{L}$ in 2010 (Zheng et al., 2002; 2010). Siling Co located in the same basin became the largest lake in Tibet, the area has more than doubled and reached $2349.46 \mathrm{~km}^{2}$. The area of the Galadandong snow mountain dropped from $666.43 \mathrm{~km}^{2}$ to $619.25 \mathrm{~km}^{2}$, a reduction of $24.48 \mathrm{~km}^{2}$.
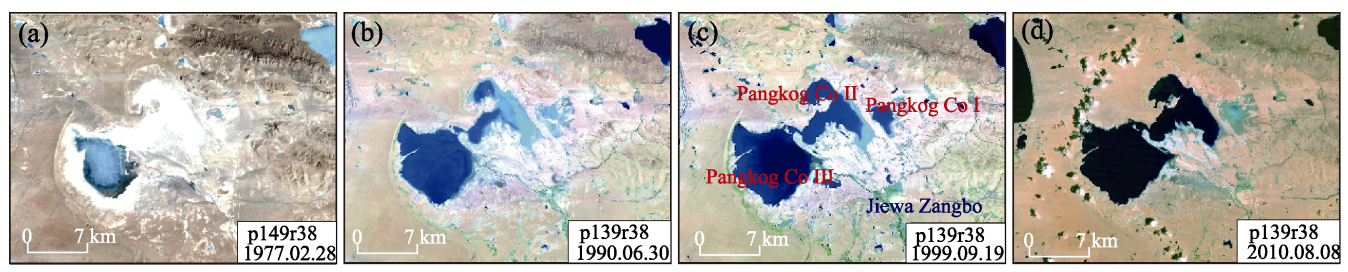

Figure 10 Remote sensing images of Bankog Co salt lake

As a whole the water level of the three lakes shows an upward trend. Due to the regional differences, the changing characteristics of the three lakes were different. Due to the large catchment area and shallow water, the influence of temperature on water level in Zabuye was stronger than that of precipitation. The peak caused by melt-water emerged in the May and June, and the secondary peak emerged with the rainfall in August and September. For Dangqiong Co, the influence of precipitation was more obvious, the peak emerged in rainy season and secondary peak emerged in June and July.

\section{Conclusions}

In this paper, climate change characteristics of Zabuye (1991-2014), Dangqiong Co (2004-2014) and Bankog Co (2001-2003) have been analyzed. The representativeness of weather parameters such as temperature, sunshine, evaporation and precipitation have been proved, considering the long-term meteorological data of field observational stations in Zabuye and Dangqiong Co salt lakes. Based on the analytical results, the climatic factors in the salt lake basin, especially the temperature, sunshine, evaporation, precipitation and wind determine the water level variation.

The following preliminary conclusions are obtained through analysis of the climate characteristics and dynamic changes of the water level in the salt lake basins.

(1) The annual mean temperature and precipitation in Zabuye, Dangqiong Co and Bankog Co basins increased gradually, but sunshine and evaporation decreased. Their water level ascended higher and higher, especially in the post-2000 period. Based on the relationship between the water changes and meteorological elements, analysis shows that water level had a positive correlation with air temperature and precipitation, and obviously a negative correlation with sunshine and evaporation.

(2) According to the analysis of climatic elements in salt lake regions and referring to the background of the climate change over the Tibetan Plateau, we can reasonably conclude that the climate in the observation area is changing to warming-wetting type and it is a partial consequence of water cycle increase by global warming. Water level rise has mainly been caused by increased precipitation, decreased evaporation and the increased meltwater of glacier retreating and permafrost degradation with the climate warming. 
(3) Seasonal variation of water level is powered largely by the supply of lake water types and the seasonal change of regional climate. The key feature is the two-level surge in the water level within one year, particularly in shallow lakes.

(4) In the absence of continuous hydrological observation data, quantitative studies about glacial runoff and meltwater of frozen soil have not been carried on. The influence of the regional climate variations on the changes of salt lakes is shown in this paper. It is necessary to study on hydrological monitoring in the future, which will help to understand water cycle process in the high altitude inland river basins of the Tibetan Plateau.

\section{Acknowledgments}

We thank the constructive review from three anonymous reviewers. Since 1990, the following professional staff have attended the work of field observation. They are He Chaoxing, Zhang Fasheng, Gao Bingqi, Bianba, Huang Xinggen, Cheng Jiabai, Qing Guanghua, Baiduo, Gu fuqing, Wei Jianming, Fan Junfeng, Zhao Jianjun, Mima, Labaciren, Cidun, Queba, Danbazhaxi, Li Shenglu, Wang Guangcai, Ma Xiaoji, Ye Yugang, Ma Wanyun, Weigang Kong and so forth. Xiuyun $\mathrm{Gu}$ and the others provided logistics support. The meteorological and hydrological data of observation in this paper are the common fruit of everyone. Sincere thanks are given to all scholars who have devoted themselves to this work.

\section{References}

Bianduo, Bianbaciren, Li L et al., 2009. The response of lake change to climate fluctuation in north Qinghai-Tibet Plateau in last 30 years. Journal of Geographical Sciences, 19(2): 131-142.

Chang W Y B, 1987. Large lakes of China. Journal of Great Lakes Research, 13(3): 235-249.

Du J, 2001. Change of temperature in Tibetan Plateau from 1961-2000. Acta Geographica Sinica, 56(33): 232-239. (in Chinese)

Du J, Yang T B, He Y, 2014. Glaciers and lakes changes and climate response in the Selin Co Basin from 1990 to 2011. Journal of Arid Land Resources and Environment, 28(12): 88-93. (in Chinese)

Jiang L G, Nielsen K, Andersen O B et al., 2017. Monitoring recent lake level variations on the Tibetan Plateau using cryosat-2 sarin mode data. Journal of Hydrology, 544: 109-124.

Kang S C, Xu Y W, You Q L et al., 2010. Review of climate and cryospheric change in the Tibetan Plateau. Environmental Research Letters, 5(1): 1-8.

Lei Y B, Yao TD, Bird B W et al., 2013. Coherent lake growth on the central Tibetan Plateau since the 1970s: Characterization and attribution. Journal of Hydrology, 483: 61-67.

Liu J S, Wang S Y, Yu S M et al., 2009. Climate warming and growth of high-elevation inland lakes on the Tibetan Plateau. Global and Planetary Change, 67(3/4): 209-217.

Lu A X, Yao T D, Wang L H, 2005. Study on the fluctuations of typical glaciers and lakes in the Tibetan Plateau using remote sensing. Journal of Glaciology and Geocryology, 27(6): 783-792. (in Chinese)

Ma N, Szilagyi J, Niu G Y et al., 2016. Evaporation variability of Nam Co Lake in the Tibetan Plateau and its role in recent rapid lake expansion. Journal of Hydrology, 537: 27-35.

Ma X B, Li D L, 2003. Analyses on air temperature and its abrupt change over Qinghai-Xizang Plateau in modern age. Plateau Meteorology, 22(5): 507-512. (in Chinese)

Niu T, Chen L X, Zhou Z J, 2004. The characteristics of climate change over the Tibetan Plateau in the last 40 years and the detection of climatic jumps. Advances in Atmospheric Sciences, 21(2): 193-203.

Qi W, Zheng M P, 2006a. Initial research on water level fluctuation discipline of Zabuye Salt Lake in Tibet. Journal of Geographical Sciences, 22(6): 693-699. (in Chinese)

Qi W, Zheng M P, 2006b. Winters and ARIMA model analyses of the lake level of salt Lake Zabuye, Tibetan Plateau. Journal of Lake Sciences, 18(1): 21-28. (in Chinese) 
Shi X H, Li L, Wang Q C et al., 2005. Climatic change and its influence on water level of Qinghai Lake. Meteorological Science and Technology, 33(1): 58-62. (in Chinese)

Shi Y F, Shen Y P, Kang E et al., 2007. Recent and future climate change in northwest China. Climatic Change, 80(3/4): 379-393.

Song C Q, Huang B, Ke L H et al., 2014a. Seasonal and abrupt changes in the water level of closed lakes on the Tibetan Plateau and implications for climate impacts. Journal of Hydrology, 514: 131-144.

Song C Q, Huang B, Ke L H et al., 2014b. Remote sensing of alpine lake water environment changes on the Tibetan Plateau and surroundings: A review. ISPRS Journal of Photogrammetry and Remote Sensing, 92: 26-37.

Wang X, Siegert F, Zhou A G et al., 2013. Glacier and glacial lake changes and their relationship in the context of climate change, central Tibetan Plateau 1972-2010. Global and Planetary Change, 111(12): 246-257.

Wu S H, Yi Y H, Zheng D et al., 2005. Climate changes in the Tibetan Plateau during the last three decades. Acta Geologica Sinica, 60(1): 3-11. (in Chinese)

Yan L J, Zheng M P, 2015a. Influence of climate change on saline lakes of the Tibet Plateau, 1973-2010. Geomorphology, 246: 68-78.

Yan L J, Zheng M P, 2015b. The response of lake variations to climate change in the past forty years: A case study of the northeastern Tibetan Plateau and adjacent areas, China. Quaternary International, 371: 31-48.

Yao T D, Pu J C, Lu A X et al., 2007. Recent glacial retreat and its impact on hydrological processes on the Tibetan Plateau, China, and surrounding regions. Arctic Antarctic \& Alpine Research, 39(4): 642-650.

Yao T D, Zhu L P, 2006. The response of environmental changes on Tibetan Plateau to global changes and adaptation strategy. Advances in Earth Science, 21(5): 459-464. (in Chinese)

Ye Q H, Yao T D, Chen F et al., 2008. Response of glacier and lake covariations to climate change in Mapam Yumco Basin on Tibetan Plateau during 1974-2003. Journal of China University of Geosciences, 19(2): 135-145.

You Q L, Kang S C, Pepin N et al., 2010. Climate warming and associated changes in atmospheric circulation in the eastern and central Tibetan Plateau from a homogenized dataset. Global and Planetary Change, 72(1/2): 11-24.

Zhao X T, Zhao Y Y, Zheng M P et al., 2011. Late Quaternary Lake Development and Denivellation of Bankog Co as well as lake evolution of southeastern North Tibetan Plateau during the Last Great Lake Period. Acta Geoscientica Sinica, 32(1): 13-26. (in Chinese)

Zhao Y Y, Zhao X T, Zheng M P et al., 2006. The denivellation of Bankog Co in the past 50 years, Tibet. Acta Geologica Sinica, 80(6): 876-884. (in Chinese)

Zhao Y Y, Zheng M P, Cai X G et al., 2006. Modern lake resources and environment on the western side of the Tibet section on the phase-II of the Qinghai-Tibet Railway. Geological Bulletin of China, 23(7): 680-685. (in Chinese)

Zheng D, Lin Z Y, Zhang X Q, 2002. Progress in studies of Tibetan Plateau and global environmental change. Earth Sci. Front, 9(1): 95-10. (in Chinese)

Zheng M P, 2014. Saline Lakes and Salt Basin Deposits in China. Beijing: Science Press.

Zheng M P, Liu X F, 2010. Hydrochemistry and minerals assemblages of salt lakes in the Qinghai-Tibet Plateau, China. Acta Geologica Sinica, 84(11): 1585-1600. (in Chinese)

Zheng M P, Qi W, Jiang X F et al., 2004. Trend of salt lake changes in the background of global warming and tactics for adaptation to the changes. Acta Geologica Sinica, 78(3): 795-807.

Zheng M P, Xiang J, Wei X J et al., 1989. Saline Lakes on the Qinghai-Xizang (Tibet) Plateau. Beijing: Science \& Technology Press. (in Chinese)

Zheng M P, Zhao Y Y, Liu J Y, 2000. Palaeoclimatic indicators of China's Quaternary saline lake sediments and hydrochemistry. Acta Geologica Sinica, 74(2): 259-265. (in Chinese)

Zhou L S, Yang W D, 1992. Discussion of the climatic change in recent 600 years and dropping of Lake water-level, Qinghai Lake drainage basin. Journal of Lake Sciences, 4(3): 25-31. (in Chinese)

Zhu L P, Xie M P, Wu Y H, 2010. Quantitative analysis of lake area variations and the influence factors from 1971 to 2004 in the Nam Co Basin of the Tibetan Plateau. Chinese Science Bulletin, 55(13): 1294-1303. 